4. Офіційний сайт фондової біржі ПФТС [Електронний ресурс]. - Режим доступу: http://pfts.ua.

5. Чому в Україні стали популярними держоблігації [Електронний ресурс]. Режим доступу: https://news.finance.ua/ua/news/-/415513/chomu-v-ukrayini-stalypopulyarnymy-derzhobligatsiyi.

*УДК 657.42:[006.032:657]

Жураковська I.B., к.е.н., доцент

Ілюшик Н.I.

Луцький національний технічний університет

\title{
ВІДОБРАЖЕННЯ ЗЕМЛІ У ЗВІТНОСТІ ЗА МСФЗ
}

У даній статті досліджено альтернативні варіанти відображення в обліку та звітності земельних активів в залежності від характеру їх використання та права власності, проведено узагальнення вимог МСФЗ щодо оцінки земель, розроблено алгоритм порядку визнання земельної ділянки певним активом, запропоновано виділити окрему групу активів, яка б відображала, що не всі права власності на земельну ділянку перейшли суб'єкту господарювання.

Ключові слова: земля, земельні ділянки, право користування майном, оцінка землі, оренда землі, звітність за МСФЗ, фінансова звітність.

\section{Zhurakovska I., Ilyushyk N.}

\section{THE LAND REFLECTION IN THE IFRS REPORT}

The article describes the theoretical principles and developed methodological and applied recommendations of alternative variants of reflecting land assets in accounting and reporting depending on their nature and ownership and generalization of IFRS requirements for land valuation.

The land is a unique object of accounting and has characteristic properties that are not repeated for other assets. The aim of the study is to summarize the requirements of IFRS for land valuation and the development of an algorithm for recognizing a land plot as a certain asset.

The principles of accounting and reporting of land are given in 10 different standards. There is no single standard, that establishes the procedure for assessing and recognizing land plots for accounting purposes. The definition of the category of "land" not given in any standard.

* Жураковська I.В., Ілюшик Н.I. 
Agricultural enterprises usually use land in their activities. Therefore, they are forced to consider the full range of international standards in order to understand which line of the report and by what cost they should reflect the proper or leased land assets.

The procedure for reflecting land in accounting and reporting directly depends on the purpose of its use. For example, if a land asset is designed for use in the production process, services, needs of the administration or is necessary for sale, then it is reflected in fixed assets and must reflecting in accordance with the requirements of IAS 16 "Property, Plant and Equipment". And if a land designed for the purpose of resale it will be reflected in inventories in compliance with the IAS 2 "Inventories".

Many scientists believe that leased land must be reflected in intangible assets. But this article justifies and proposes to highlight a separate group of assets that would reflect, that not all ownership of the land has passed to the economic entity.

The research reports of Ukrainian enterprises that lands are most often reflected in the form of fixed assets, investment property and sometimes combined assets.

The research substantiated that the lack of a definition and detailed instructions for land accounting indicates that land accounting may have particularity as depending on national legislation. This necessitates the development of an internal standard for land accounting, which conforms to IFRS.

Key words: the land, the land assets, the right to use property, the valuation of land, the lease of land, IFRS, the reporting, the financial statements.

Жураковская И.В., Илюшик Н.И.

\section{ОТРАЖЕНИЕ ЗЕМЛИ В ОТЧЕТНОСТИ ЗА МСФЗ}

В данной статье исследованы альтернативные варианты отражения в учете и отчетности земельных активов в зависимости от характера их использования и права собственности, проведено обобщение требований МСФО по оценке земель, разработан алгоритм порядка признания земельного участка определенным активом, предложено выделить отдельную группу активов, которая бы отражала, что не все права собственности на земельный участок перешли субъекту хозяйствования.

Ключевые слова: земля, земельные участки, право пользования имуществом, оценка земли, аренда земли, отчетность по МСФО, финансовая отчетность.

Постановка проблеми у загальному вигляді та її зв'язок 3 важливими науковими та практичними завданнями. Земельний фонд України становить 5,7\% території Свропи. Близько 71\% території України (42,7 млн. га) підпадає під категорію сільськогосподарських угідь. Більше 10 мільйонів гектарів цих земель належить державі, що становить близько 25\% від загальної кількості сільськогосподарських угідь в Україні [25]. Таке національне багатство не стало повноправним учасником господарського обороту. Мораторій на продаж сільськогосподарських угідь в Україні зумовив 
появу нових видів оренди землі (зокрема емфітевзис), які по суті вже визначили перехід права власності на земельні ресурси, але офіційних заяв ще немає. Знахідкою для українських реалій земельного ринку є впровадження більш прозорого механізму відображення землі у звітності підприємств за МСФ3 16 «Оренда», що полягає у визнанні активом не лише прав власності, а й прав користування. Для земельних ділянок в Україні такі трактування активів в умовах мораторію є вкрай актуальними, адже дозволить сільськогосподарським товаровиробникам поставити земельні ділянки на баланс і оцінити їх, що буде першим кроком до формування ринку землі. Облікове забезпечення орендних земельних відносин може стати маленьким кроком на шляху до його впровадження.

Аналіз останніх досліджень, у яких започатковано вирішення проблеми. Дослідженням землі як об'єкта обліку займались багато науковців, зокрема Китайчук Т.Г. [3], Підвисоцька Л.Я. [20], Правдюк Н.Л. та Іщенко Я.П. [21] визначають необхідність виокремлення землі як окремого об'єкта обліку, зважаючи на специфічні біологічні, економічні та стратегічні особливості такого активу, Марчук У.О. [4], Жук В.М. [1] порівнюють процес оцінки земельних активів та фактори, які впливають на цю оцінку, в різних країнах, Пантюхова А. В. [19] розглядає відмінності обліку земель між національними та міжнародними стандартами, Метелиця В.М. [5] та Остапчук С. М. [18] наголошують на необхідності формування окремого стандарту, який би визначав порядок обліку земель. Остапчук С.В. взагалі приділив значну увагу обліку та відображенню земельних активів в звітності [16], порядку їх оцінювання [17].

Проте єдині рекомендації з обліку земель і відображення їх у звітності за МСФЗ відсутні. Дослідження представляють фрагментальні узагальнення можливих варіантів обліку землі в залежності від їі призначення.

Цілі статті. Метою дослідження є вивчення порядку відображення землі у звітності згідно МСФЗ та визначення основних напрямків розвитку облікової теорії для формування ринку землі в Україні і визнання їі у складі активів.

Виклад основного матеріалу дослідження з повним обгрунтуванням отриманих наукових результатів. В Україні близько 21,5 млн. га сільськогосподарських угідь обробляють близько 45000 
комерційних виробників [25]. Середня ціна землі в Болгарії 4500 доларів за 1га. Тобто, якщо врахувати, що площа сільськогосподарських земель України, які обробляються підприємства, що подають звітність становить 21,5 млн.га, то вартість земель на їх балансах (якщо припустити таку ж вартість) має становить мінімум 96750 млн доларів. За даними Державної служби статистики вартість землі на балансі підприємств України складає 33397 млн. грн. (табл. 1). Це в рази менше європейської практики, що вказує на недооцінку землі або ж іiі не відображення. Ми припускаємо, що існують обидві ці причини.

Таблиця 1

Вартість основних засобів на балансі підприємств України за видами економічної діяльності*

\begin{tabular}{|l|l|c|c|}
\hline \multirow{2}{*}{$\begin{array}{c}\text { № } \\
3 / \Pi\end{array}$} & \multicolumn{1}{|c|}{ Назва виду економічної діяльності } & \multicolumn{2}{|c|}{$\begin{array}{c}\text { Вартість основних засобів } \\
\text { на кінець 2017 року }\end{array}$} \\
\cline { 3 - 4 } & \multicolumn{1}{|c|}{ тис. грн. } & $\%$ \\
\hline 1 & Усього & 7733904663 & 100,00 \\
\hline 2 & $\begin{array}{l}\text { Сільське господарство, лісове господарство та } \\
\text { рибне господарство }\end{array}$ & 341622274 & 4,42 \\
\hline 3 & $\begin{array}{l}\text { Сільське господарство, мисливство та надання } \\
\text { пов язаних із ними послуг }\end{array}$ & 335302471 & 4,34 \\
\hline 4 & Лісове господарство та лісозаготівлі & 5308341 & 0,07 \\
\hline 5 & Рибне господарство & 1011462 & 0,01 \\
\hline 6 & Промисловість & 2454482642 & 31,74 \\
\hline & Із загального підсумку & & 0,00 \\
\hline 7 & Вартість тварин & 37649 & 0,00 \\
\hline 8 & Вартість земельних ділянок & 33397908 & 0,43 \\
\hline 9 & Вартість інвестиційної нерухомості & 96515600 & 1,25 \\
\hline 10 & Вартість довгострокових біологічних активів & 33603466 & 0,43 \\
\hline
\end{tabular}

*Складено за даними Державної служби статистики.

Нами вивчено зміст всього пакету МСФЗ та МСБО. Про землю як об'єкт, який необхідно розкривати у звітності, йде мова у 10 міжнародних стандартах обліку і звітності (тобто термін «земля» згадується безпосередньо). Не існує єдиного стандарту, який встановлює порядок оцінки та визнання земельних ділянок для цілей бухгалтерського обліку. При чому визначення категорії «земля» чи «земельні ділянки» взагалі не наводиться в жодному стандарті. 
Тому для землі, як об'єкта обліку в Україні, доцільно використовувати визначення земельної ділянки з Земельного кодексу України від 25.10.2001 № 2768-III статті 79. Відсутність визначення вказує на те, що облік земельних ділянок може мати особливості в залежності від національного законодавства.

В одній із своїх багаточисленних праць про землю Жук В.М. пояснює відсутність окремого стандарту щодо обліку земельних ресурсів: «Відсутність у міжнародних стандартах положень обліку земель сільськогосподарського призначення можна пояснити відношенням замовників МСФЗ транснаціональних корпорацій до цього природного ресурсу. ТНК, як правило, намагаються за безцінь експлуатувати природні ресурси, а, відтак нав'язувати світові через МСФЗ пріоритетність інших цінностей» [2].

Детальний аналіз стандартів показав, що в обліку і звітності залежно від призначення землю відображаються у складі: запасів (товарів); основних засобів; державних грантів; інвестиційної нерухомості; комбінованих активів (земля в комплексі з біологічним активом); прав користування.

Як здавалось на перший погляд, розкриття інформації про землю у фінансовій звітності регулюватиметься МСБО 41 «Сільське господарство», та даний стандарт визначає лише один 3 можливий варіантів обліку земельних ділянок. Тобто сільськогосподарські підприємства, які лише в рідких випадках не використовують в процесі своєї діяльності землю, вимушені розглянути увесь комплект міжнародних стандартів, щоб зрозуміти, в якому рядку звітності та за якої оцінкою їм слід відображати наявні або орендовані земельні ділянки.

Дослідження звітності підприємств України завдяки ресурсу (http://smida.gov.ua) показало, що земельні ділянки найчастіше зустрічаються у вигляді основних засобів, інвестиційної нерухомості, в рідких випадках - комбінованих активів. I, зважаючи на особливості українського законодавства, більшість земельних ділянок використовуються на правах оренди.

Якщо земля утримується на підприємстві 3 метою використання в процесі звичайної діяльності, то вона визнаватиметься основним засобом, а іiі облік регламентуватиметься МСБО 16 «Осно- 
вні засоби» (надалі - МСБО 16). В такому випадку земля може входити до окремого класу активів «земля» або «земля та будівлі». Проте при можливості землю та будівлі слід обліковувати окремо, незважаючи на те чи купували ці активи одночасно. Це зумовлено тим, що зазвичай земля не має встановленого строку експлуатації, а отже й не амортизується. Будівлі ж в свою чергу мають обмежений строк використання і підлягають амортизації.

Параграф 25 МСБО 41 «Сільське господарство» (надалі МПСБО 41) висовує ще одне можливе відображення землі в обліку - в комплексі із біологічними активами. Таким чином земля відображається, якщо вона фізично невіддільна від біологічного активу (наприклад, дерева в лісовому господарстві). Стандарт називає комплекс біологічних активів, необробленої землі та заходів 3 культивації землі «комбінованими активами». Тобто в обліку і звітності земля не буде виступати як окремий об'єкт обліку, який потребує своєї оцінки, визнання і т.д.

Доволі поширеним випадком є відображення землі в обліку і звітності як інвестиційної нерухомості. Земля класифікується як інвестиційна нерухомість, якщо вона є власністю підприємства або передана підприємству на умовах фінансової оренди для одержання орендних платежів або збільшення вартості капіталу, а не для використання в процесі операційної діяльності чи продажу. Відмінною рисою землі як інвестиційної нерухомості є те, що вона приносить грошові потоки незалежно від інших активів суб'єкта господарювання. Земля як об'єкт інвестиційної нерухомості може обліковуватись в комплексі з активами, які є невіддільними від неї, або ж якщо дохід орендодавця буде пов'язаний із земельною ділянкою, яка має такий актив (наприклад, біологічні активи, захисні споруди від вітрів та хижих звірів, осушувальні системи).

В численних дослідженнях [3, 17, 19 та ін] право користування земельними ділянками відносять до нематеріальних активів підприємства, зазначаючи, що такі вимоги викладено в МСБО 38 «Нематеріальні активи». Проте дослідження цього стандарту показало, що в ньому нематеріальним активом згадується право на іпотечне обслуговування, а не право користування земельною ділянкою. 
Відображення операцій з оренди земельних активів регулюється МСБО 17 «Оренда» (надалі - МСБО 17). 32019 року вступає в дію МСФ3 16 «Оренда» в якому зберігся старий порядок обліку оренди у орендодавця. Для звітності орендаря стались суттєві зміни. Орендар у момент укладення договору повинен оцінити, чи $є$ договір в цілому або його окремі компоненти договором оренди. МСФ3 16 визначає оренду на підставі того, чи контролює орендатор використання ідентифікованого активу протягом певного періоду часу, який може бути визначений. Ці характеристики виконуються, якщо орендатор може приймати важливі рішення про використання активу аналогічно тому, як він приймає рішення відносно активів, що йому належать. Відповідно до МСФЗ 16 орендар на дату початку оренди повинен оцінювати та визнавати на балансі актив у формі права користування. Таким чином для орендарів майже вся оренда стає фінансовою і передбачає відображення орендованих активів на балансі у вигляді прав користування.

Наші дослідження показали, що операції з землею зачіпають практично всі форми звітності, що узагальнено в табл. 2.

До кожного об'єкта, в складі кого відображається земельна ділянка, використовуються різні види оцінок, наведені нами вище. Виникає ситуація, коли одна і та ж ділянка в залежності від їі використання може бути оцінена за різною вартістю.

Китайчук Т.Г. наголошує, що «...без удосконалення бухгалтерського обліку земельних ділянок, без пошуку найбільш раціональних та ефективних методів обліку і контролю не можуть бути успішно вирішені і завдання земельної реформи». [3]

В сучасних умовах, можна виділити два шляхи формування методології бухгалтерського обліку земель сільськогосподарського призначення, яка б відповідала національним інтересам: 1) зміна методології МСФ3; 2) розробка власного галузевого стандарту» [18]. Методологія МСФЗ зазнала змін через впровадження МСФЗ 16 «Оренда», яке змінило визнання оренди. 31 січня 2019 року орендою визнаватиметься договір в цілому або окремі компоненти за договором оренди. В іншому випадку визнаються послуги. 
Економічні науки". - Серія "Облік і фінанси". - Випуск 15 (57). - 2018.

Таблиця 2

Оцінка та відображення землі у звітності за МСФЗ

\begin{tabular}{|c|c|}
\hline $\begin{array}{l}\text { Види земельних діля- } \\
\text { нок згідно МСФЗ }\end{array}$ & Оцінка земельної ділянки у звітності \\
\hline $\begin{array}{l}\text { Земля як основний } \\
\text { засіб }\end{array}$ & $\begin{array}{c}\text { За собівартістю або переоціненою вартістю } \\
\text { (п.7-15 та п.31-42 МСБО 16) }\end{array}$ \\
\hline $\begin{array}{c}\text { Земля як комбінова- } \\
\text { ний актив (земля в } \\
\text { поєднанні з біологіч- } \\
\text { ним активом) }\end{array}$ & $\begin{array}{c}\text { За справедливою вартістю, теперішньою вар- } \\
\text { тістю очікуваних чистих грошових потоків від } \\
\text { такого активу або за собівартістю, зменшеною } \\
\text { на збитки від зменшення корисності (п.12, 20, } \\
30 \text { МСБО 41) } \\
\end{array}$ \\
\hline $\begin{array}{c}\text { Земля як інвестиційна } \\
\text { нерухомість }\end{array}$ & $\begin{array}{l}\text { За собівартістю або справедливою вартістю } \\
\text { (п.32А МСБО 40) }\end{array}$ \\
\hline $\begin{array}{l}\text { Земля передана в } \\
\text { оренду }\end{array}$ & Залежить від виду оренди \\
\hline $\begin{array}{c}\text { Земля як актив з пра- } \\
\text { ва користування } \\
\text { (отримана в оренду) }\end{array}$ & $\begin{array}{l}\text { Земельна ділянка визнається активом з права } \\
\text { користування і оцінюється за собівартістю, яка } \\
\text { включає: } \\
\text { - оцінку зобов'язання з оренди, яке оцінюється } \\
\text { за теперішньою вартістю орендних платежів, } \\
\text { не сплачених на таку дату; } \\
\text { - орендні платежі, здійснені на/до дати почат- } \\
\text { ку оренди, за вирахуванням отриманих стиму- } \\
\text { лів до оренди; } \\
\text { - первісні прямі витрати орендаря; } \\
\text { - витрати пов'язані із переміщенням, віднов- } \\
\text { лення землі тощо, якщо він відображає зо- } \\
\text { бов'язання за цими витратами, а не у випадку, } \\
\text { коли ці витрати понесені для виробництва } \\
\text { запасів (п.24-27 МСФ3 16) } \\
\text { Після дати початку оренди буде оцінюватись } \\
\text { відповідно до напрямів використання та облі- } \\
\text { кової політики підприємства (за справедли- } \\
\text { вою, переоціненою вартістю тощо). (п.29-35 } \\
\text { МСФЗ 16) }\end{array}$ \\
\hline
\end{tabular}

Алгоритм відображення земельних ділянок у складі активів наведено на рис. 1. 
Економічні науки". - Серія "Облік і фінанси". - Випуск 15 (57). - 2018.

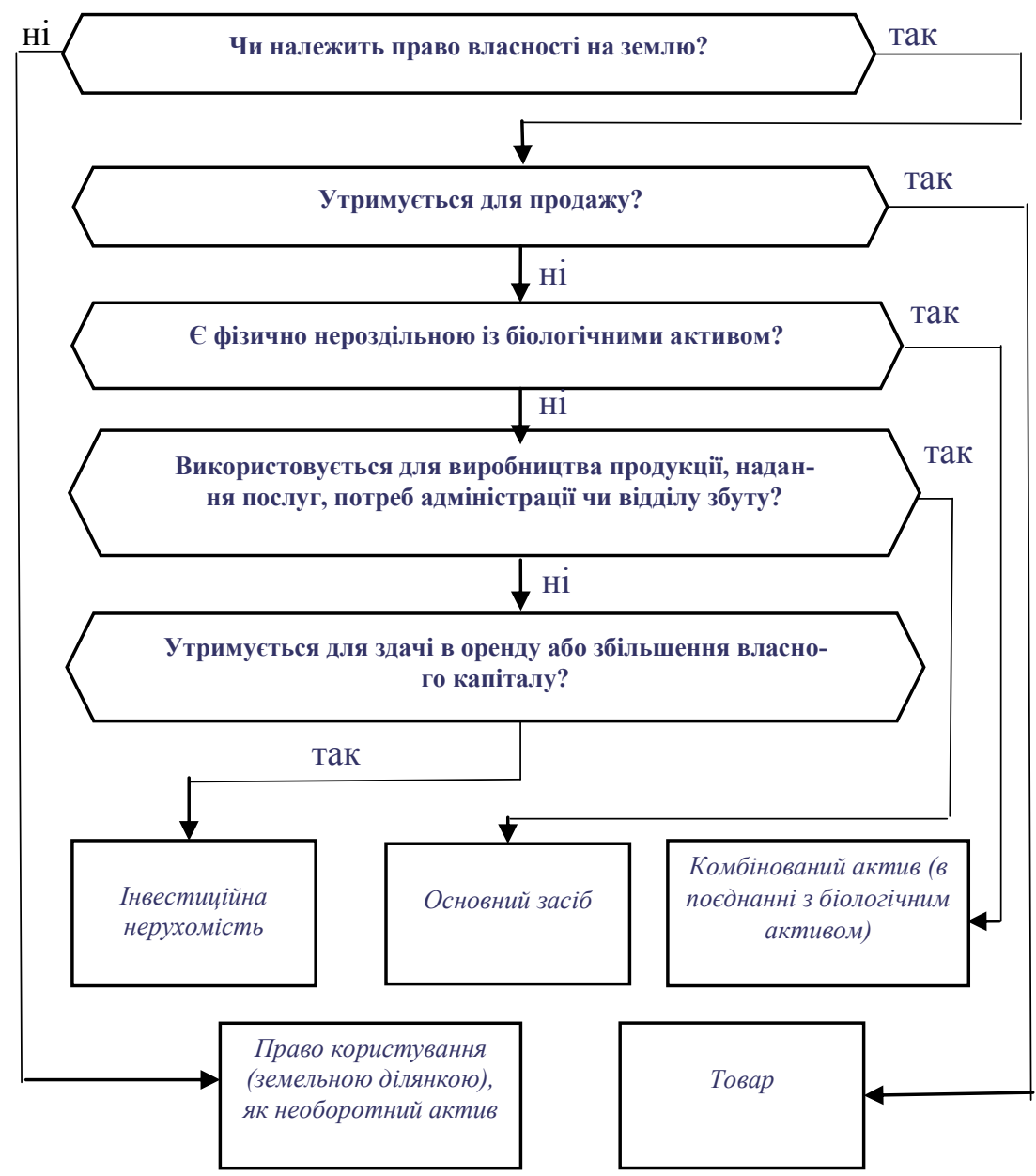

Рис.1. Алгоритм відображення земельних ділянок у складі активів підприємства

Всі права власності на земельну ділянку у вітчизняній практиці відображаються на рахунку 122 «Права користування майном». Його використання в складі нематеріальних активів не відповідає сутності цього виду активів. Нематеріальні активи містять в своїй основі інтелектуальну чи творчу складову. Так, наприклад, 
якщо ми бачимо в звіті велику вартість нематеріальних активів, ми все ж таки схиляємось до думки, що підприємство володіє інтелектуальною власністю. А права на користування земельними чи природними ресурсами слід відображати окремо.

Висновки. В пакеті МСФЗ та МСБО не існує єдиного стандарту, який встановлює порядок оцінки та визнання земельних ділянок для цілей бухгалтерського обліку. Визначення категорії «земля» чи «земельні ділянки» взагалі не наводиться в жодному стандарті. Це вказує на те, що розробниками МСФЗ враховано, що облік земельних ділянок може мати особливості в залежності від національного законодавства, що потребує розробки внутрішнього стандарту обліку землі, який не суперечитиме МСФЗ.

В обліку і звітності залежно від призначення землю відображаються у складі: запасів (товарів); основних засобів; державних грантів; інвестиційної нерухомості; комбінованих активів (земля в комплексі з біологічним активом), прав користування. Для кожного об'єктавикористовуються різні види оцінок. Це призводить до того, що одна і та ж ділянка в залежності від іï призначення в даний момент часу може бути оцінена за різною вартістю, що вимагає проведення подальших детальних досліджень доцільності такого підходу.

Використання у вітчизняній практиці рахунку 122 «Права користування майном» в складі нематеріальних активів не відповідає сутності операцій оренди землі. Нематеріальні активи, на нашу думу, містять в своїй основі інтелектуальну чи творчу складову, так як наявність в звіті великої вартості нематеріальних активів має свідчити про наявність інтелектуальної власності, а не прав оренди на нерухомість. Запропоновано права на користування земельними чи природними ресурсами відображати окремо в складі необоротних активів, що дозволить користувачам звітності оцінити об'єми залучених до господарського обороту активів, на яких не перейшло право власності.

1. Жук В. М. Стандартизація бухгалтерського обліку земель сільськогосподарського призначення / В.М. Жук // Запровадження МСФЗ в Україні: проблеми та перспективи для аграрного сектору. VII Міжнародна науковопрактична конференція. ННЦ «Інститут аграрної економіки» НААН, 25 листопада 2011 р.: 
збірник тез та виступів / Відпов. за вип. Б.В. Мельничук. - К.: ТОВ «ЮрАгроВеста», 2011. - 438 с. - С. 1621.

2. Земельний кодекс України від 25.10.2001 № 2768-III [Електронний ресурс] / Режим доступу: http://zakon.rada.gov.ua/laws/show/2768-14

3. Китайчук Т.Г. Особливості обліку землі та земельних відносин. / Китайчук Т.Г., Мудрик Ю.М. // Зб. наук. праць Таврійськ. держ. агро-технолог. ун-ту (економічні науки). - 2013. - № 2. - С. 137-143.

4. Марчук У.О. Оцінка землі у міжнародній обліковій системі / Марчук У.О. // Збірник наукових праць ВНАУ. Серія: Економічні науки. - 2017. - №24 (2 частина) - С. 136-140.

5. Метелиця В.М. Запровадження стандарту обліку земель сільськогосподарського призначення як інституту бухгалтерської професії. / Метелиця В.М. // Науково-практичний журнал «Бухгалтерський облік і аудит» - 2013. - №3 - С. 27 33.

6. Міжнародний стандарт бухгалтерського обліку (МСБО 16) «Основні засоби» [Електронний ресурс] / Режим доступу: http://zakon.rada.gov.ua/laws/show/929_014.

7. Міжнародний стандарт бухгалтерського обліку (МСБО 17) «Оренда» [Електронний ресурс] / Режим доступу: http://zakon.rada.gov.ua/laws/show/929_018.

8. Міжнародний стандарт бухгалтерського обліку (МСБО 18) «Дохід» [Електронний ресурс] / Режим доступу: http://zakon.rada.gov.ua/laws/show/929_025.

9. Міжнародний стандарт бухгалтерського обліку (МСБО 2) «Запаси» [Електронний ресурс] / Режим доступу: http://zakon.rada.gov.ua/laws/show/929_021.

10. Міжнародний стандарт бухгалтерського обліку (МСБО 20) «Облік державних грантів і розкриття інформації про державну допомогу» [Електронний ресурс] / Режим доступу: http://zakon.rada.gov.ua/laws/show/929_041.

11. Міжнародний стандарт бухгалтерського обліку (МСБО- 36) «Зменшення корисності активів» [Електронний ресурс] / Режим доступу: http://zakon.rada. gov.ua/laws/show/929_047.

12. Міжнародний стандарт бухгалтерського обліку (МСБО 40) «Інвестиційна нерухомість" [Електронний ресурс] / Режим доступу: http://zakon.rada.gov. ua/laws/show/929_026.

13. Міжнародний стандарт бухгалтерського обліку (МСБО 41) «Сільське господарство» [Електронний ресурс] / Режим доступу: http://zakon.rada. gov.ua/laws/show/929_027.

14. Міжнародний стандарт фінансової звітності (МСБО 13) «Оцінка справедливої вартості» [Електронний ресурс] / Режим доступу: http://zakon.rada.gov. ua/laws/show/929_068\#n2.

15. Міжнародний стандарт фінансової звітності для малих та середніх підприємств (МСФЗ для МСП) [Електронний ресурс] / Режим доступу: http://zakon. rada.gov.ua/laws/show/929_063.

16. Остапчук С. М. Облік земельних ділянок та прав користування ними в системі міжнародних стандартів фінансової звітності. / Остапчук С. М. // Економіка АПК - 2013. - №7. - С. 134-141.

17. Остапчук С. М. Облікова оцінка земельних ресурсів: міжнародний досвід та вітчизняна практика. / Остапчук С. М. // ВІСНИК ЖДТУ. Серія: Економічні науки. - 2012. - №2 (60). - С. 79-85. 
18. Остапчук С. М. Стандартизація бухгалтерського обліку земель сільськогосподарського призначення / С. М. Остапчук. // Облік і фінанси АПК. - 2012. - №3. - C. 62-71.

19. Пантюхова А. В. Облік земельних ресурсів за міжнародними та національними стандартами з урахуванням екологічної складової. / Пантюхова А. В. // Вісник НТУ «ХПІ». - 2013. - №53 (1026) - С. 96-103.

20. Підвисоцька Л.Я. Облік та звітність земельних ресурсів: проблеми організації та методики / Підвисоцька Л.Я. // Економіка. Управління. Інновації. - 2016. №3 (18).

21. Правдюк Н.Л. Особливості земель сільськогосподарського призначення як об'єкта бухгалтерського обліку / Правдюк Н.Л., Іщенко Я.П. // Збірник наукових праць ВНАУ. Серія: Економічні науки. - 2012. - №1 (56) - С. 211-217.

22. Тлумачення КТМФЗ 5. Права на частки у фондах на виведення з експлуатації, відновлення та екологічну реабілітацію [Електронний ресурс] / Режим доступу: http://zakon.rada.gov.ua/laws/show/929_055\#n2.

23. Соколова Н. Облік договорів оренди: на які зміни звернути увагу [Електронний pecyрc] / Режим доступу: http:/agravery.com/uk/posts/author/show?slug=oblik-dogovorivorendi-na-aki-zmini-zvernuti-uvagu.

24. Карпачова О. МСФЗ 16 «ОРЕНДА» [Електронний ресурс] / Режим доступу: https://zakon.help/article/msfz-16-orenda/

25. Establishment of a land market in Ukraine: current state and prospects [Електронний ресурс] / Режим доступу: file:///C:/Users/Admin/Downloads/2018+Land+market+overview\%20(1).pdf.

* УДК 338.242.2

Іщук Л.І., к.е.н., доцент

Ніколаєва А.М., к.е.н., доцент

Харчук С.В.

Луцький національний технічний університет

\section{ШЛЯХИ ПОКРАЩЕННЯ ФІНАНСОВОГО СТАНУ ПІДПРИЄМСТВА В СУЧАСНИХ ЕКОНОМІЧНИХ УМОВАХ}

У статті розкрито сутність поняття фінансового стану підприємства, визначено дестабілізуючі фактори впливу на фінансовий стан та виділено шляхи його покращення.

Ключові слова: фінансовий стан, підприємство, напрям покращення фінансового стану.

* Іщук Л.І., Ніколаєва А.М., Харчук С.В. 